\title{
Development of Mobile Application Framework Based on Competency-Based Education for Technical and Vocational Education
}

\author{
Khairul Anuar Abdul Rahman ${ }^{*}$, Norazwani Abd Jalil ${ }^{1}$, Mohd Azhar M.Arsad ${ }^{2}$, \\ Suhaizal Hashim ${ }^{1}$, Mohd Bekri Rahim ${ }^{1}$, Faizal Amin Nur Yunus ${ }^{1}$, Nizamuddin \\ Razali $^{1}$, Mohd Erfy Ismail ${ }^{1}$
}

${ }^{1}$ Faculty of Technical and Vocational Education,

Universiti Tun Hussein Onn Malaysia, 86400 Parit Raja, Batu Pahat, Johor, MALAYSIA

${ }^{2}$ V3X MALAYSIA Sdn Bhd, No. 87A, Jalan Pulai 7, Taman Pulai Utama, 81310 Skudai, Johor, MALAYSIA

*Corresponding Author

DOI: https://doi.org/10.30880/jtet.2021.13.02.005

Received 04 ${ }^{\text {th }}$ January 2021; Accepted $3^{\text {rd }}$ March 2021; Available online 30 ${ }^{\text {th }}$ June 2021 Month

\begin{abstract}
This study aimed to develop a mobile application framework based on Competency-Based Education (CBE) in Technical and Vocational Education. CBE approach in teaching and learning should be applied because this approach is suitable for skill-based education. In technological advancement, the mobile application approach causes students to have their own control in teaching and to learn to be implemented seamlessly and more effectively. This research is a qualitative method that has gone through three phases to form a framework for the mobile app based on CBE. The instruments used are structured interview and evaluators' reliability review form. The study sample consisted of 6 experts in CBE and technology for the interview session and 3 experts in TVET for reliability data verification. The raw data obtained from the interviews have gone through a thematic analysis process using Atlas.ti software. The results show 36 items identified as characteristics of CBE in the mobile application, with the average Cohen Kappa Index Approval coefficient was 0.9 indicating a very good reliability scale. The findings of this study consist of 33 items with seven constructs approved after the inter-rater reliability among the expert. The implication from this research could be used as guidance in the development of the instructional mobile application, particularly in Technical and Vocational Education and as an instrument for evaluating existing instructional mobile applications.
\end{abstract}

Keywords: Technology, competency-based education, mobile application, framework, development

\section{Introduction}

As technology has become mainstream in the 21 st century, the effectiveness of learning will be enhanced (Basharat, 2018) with the use of mobile applications in teaching and learning (T\&L). The transition of T\&L using traditional methods to technology-based T\&L can have a positive impact on students (Jasmi et al., 2011; Toth et al., 2010). However, based on the research done, it is found that conventional or traditional T\&L methods are still used in most Technical Education and Vocational Training (TVET) institutions in Malaysia (Azmi et al., 2017). In TVET, a T\&L skill and process that students need to master is not something that can be understood easily in a short time. It requires students to follow the T\&L effectively so that it can give them a return to the attention given during the T\&L session (Abdul Rahman, 2016). Traditional teaching methods are seen as having weaknesses that can make students feel bored and less motivated. 
This method is focused only on the teacher and ignores the student's overall involvement. Besides, there will be some students who do not concentrate or who sleep during the T\&L session because they may be weak or less motivated (Graham, 2014; Lee, 2018; Licorish, Owen, Daniel, \& George, 2018).

Furthermore, the application of technical skills to TVET students is often used as a demonstration method (Shaharuddin \& Ahmad Khari, 2011). This method is beneficial and helpful in imparting technical skills and knowledge to students; however, it may take some time for an explanation and repetition of work steps to result in increased learning time (Abdul Rahman, 2016). Therefore, if the learning time itself is limited, it will not be able to give the students full control even when the T\&L session is well conducted. There is a general awareness that students' skills taught using traditional teaching methods are limited (Serrano, O'Brien, Roberts, \& Whyte, 2018). Other than that, different levels of student ability and student background may result in lectures being used only by some students (Hernandez-Ramos, 2007; Shaharuddin \& Ahmad Khairi, 2011). For students who do not understand the teaching sessions provided, the steps they have learned can never be repeated. Students also do not have easy access to the material that will help them understand the steps (Masran, Marian, Nur Yunus, Rahim, \& Abd Baser, 2017). Thus, academics can no longer teach in the same way that they trained a decade ago but have to make the paradigm shift to accommodate the diverse mobile-generation student population in their teaching style (Muslimin et al., 2017). Besides, the global issues now are Covid-19 which has given limitation to physical class. Students and teachers face lack of communication, knowledge transfer and teaching and learning through face to face (Simah, Che Aleha, Azni Yati et al., 2021). Furthermore, course learning outcome based on skill is difficult to achieve if the physical class is unable to be run. This issues cause student lack of motivation and guidance (Lokman, Nurul Qistina \& Mohd Hanafi, 2009).

Competency-Based Education (CBE) defined by Sullivan (1995) as one of the most commonly used teaching approaches in skills learning compared to abstract. CBE approaches as students' need for one-on-one skills, ranging from smaller components to larger learning goals. Ayonmike, Okwelle, and Okeke (2014) stated that students would be evaluated based on their abilities. This approach is compatible with TVET because its curriculum focuses on skill acquisition and oriented towards the world of work. The CBE approach in T\&L enables students to take the time they need to understand something large or small (Educause, 2014). This is because the traditional approach is more of a timebased approach where the instructor will spend the assigned syllabus in the allotted time, and differences in student ability are not considered in the T\&L process (Kandar \& Asnul Dahar, 2006). According to Eteokleous and Ktoridou (2009) and Norris, Hossain, and Soloway (2011), looking at the broader context, mobile devices are also responsible for new art, fields of work, languages, commerce, and learning. Mobile learning is defined as learning that encompasses a variety of contexts and through social interaction using mobile devices (Crompton \& Burke, 2018). According to Hwang and Tsai (2011), mobile learning uses technology to facilitate learning. It also refers to the capabilities of mobile devices that have been brought into the context of the physical classroom as well as student activities and their involvement in learning (Ali \& Mohd Arshad, 2016).

Information technology systems must also be student-centered and academic-based in their data organization. For the construction of the framework, this study will refer to research by Glowa and Patrick (2013) that has focused on design considerations for CBE in information technology. In developing an ideal mobile application development, it should have the following support functions such as student profile, learning management space, personal workspace, assessment management, learning materials management, curriculum management, performance management, reporting and analysis, and finally, management of learning resources. In a comprehensive approach to mobile applications, data standards, data movement, and resilience, consistency, and ability across multiple systems are crucial. Mobile app users will have different views depending on their role. However, most important is the need to enable the mastery of personal skills and reliable reporting.

Researchers have found that the main issue is the use of teaching methods using conventional or traditional T\&L methods despite advances in educational technology. Traditional teaching methods are seen as having weaknesses that can make students feel bored and less motivated. Students also do not have easy access to the material and there is a general awareness that students' skills taught using traditional teaching methods are limited. Additionally, the Covid-19 issues today add more limitation to a physical class. Therefore, as the CBE approach is considered suitable for TVET, researchers using the features of the CBE approach that will be identified to develop a mobile application framework based on CBE for Technical and Vocational Education (TVET). Therefore, this study will include identifying the features of the CBE approach in mobile applications as well as the development of mobile application frameworks conceptualizing the CBE approach.

\section{Methodology}

In this study, the study method used is a qualitative method of phenomenology. It is selected because according to Creswell (2013), qualitative studies are subjective and are based on observation and interpretation of data through narrative, ethnography, interviews, documents, and more. It also provides more detail on emotions, behaviours, and things that cannot be analysed using numbers or math. The research using qualitative methods is useful when a problem needs to be explored in-depth, requires complex and detailed understanding, encourages individuals to share stories, and more (Creswell, 2013). 
This study used a purposive sampling method to get data for developing a mobile application framework based on Competency-Based Education for Technical and Vocational Education. This research has two phases where the first phase involving a structured interview with an expert while the second phase is to get approval from the expert. For the first phase, researchers have conducted structured interviews with six experts in educational technology and CBE in Malaysia. This expert has at least 10 years of experience in applying CBE and technology in their teaching and learning. Before the actual interviews were conducted, structured interview transcripts were confirmed in advance by one expert in the language field and one counsellor where both have experienced above 15 years in their field to make sure the content meaning is clear and easy to understand. Next, pilot interviews were conducted to identify if there are any weaknesses to the interview transcripts. Once improvements were made, actual interviews were carried out. The raw data from the interviews conducted were recorded, compiled, analyzed and interpreted to make it meaningful in this study. These data were processed using ATLAS.ti software. Data were analyzed through three procedures which were reduction, verification and presentation of data (Miles \& Huberman, 1994). In the process of data analysis, the researcher read the transcript of the interviews several times, select and summarize data that are meaningful to the study. Data were classified into meaningful units called 'segmenting' while data that did not give any significance was dropped. Next, in the second phase, the data selected was given to three experts in educational technology and Competency-Based Education to review and command. This process was done to get interrater reliability of the construct using the Cohen Kappa Index Approval Rating Scale. The Cohen Kappa Index Approval Coefficient will be used to determine the degree of agreement of the findings.

\section{Result}

Once all the data were transcribed, the researchers used a coding system based on the recommendations made by Marohaini (Marohaini, 2001). Fixing a code for each transcript and segment is important to facilitate the process of retrieving the original data and to ease cross-referencing of information when writing and reporting (Marohaini, 2001). Next, the researchers have verified the interview data to ensure the validity and reliability of the findings of the interview data. The result of the interview analysis was 36 features of the CBE in mobile applications and has been categorized into 7 constructs adapted from Glowa and Patrick (2013), namely learning management, personal workspace, assessment management, learning materials management, curriculum and learning resources, performance management, and finally, reporting and analysis. Learning management integrates components of curriculum, instruction, portfolios, communications, student information, and other features to facilitate and facilitate active learning. The personal workspace provides an interface for users to manage data, content, lesson plans and more.

Assessment management includes the ability to record assessment results from the offline assessment conducted, plan and execute the online assessment administration. In addition, in competency education, assessment management must also be able to record the progress of an assessment. Learning materials management enables the management and collection of appropriate content and makes it available to those who need it. Curriculum management and learning resources are linked to efficiency in particular learning materials and resource management in the sharing and storage of learning resources. Performance management is chosen by researchers because it focuses on individual development and optimizing performance. This includes data analysis of student progress and the use of resources to support teachers in improving performance. Student-based reporting and analysis-based constructs track student progress toward better mastery and provide teachers with individual or group progress indicators. A complete table of the constructs and the elements of CBE in the mobile application that is said by the research participant can be seen in Table 1 below.

Table 1 - A complete table of the constructs and the elements of CBE in mobile application that being said by the research participant

\begin{tabular}{|c|c|c|c|c|c|c|}
\hline \multirow{2}{*}{ Learning Management } & \multicolumn{6}{|c|}{ Research Participant (PS) } \\
\hline & PS 1 & PS 2 & PS 3 & PS 4 & PS 5 & PS 6 \\
\hline Provides application usage manual for lecturers & $\checkmark$ & & & & & $\checkmark$ \\
\hline Provides application usage manuals for students & $\checkmark$ & & & & $\checkmark$ & \\
\hline Ensure profile management is possible & & & & $\checkmark$ & & \\
\hline Able to create a learning group & & & $\checkmark$ & $\checkmark$ & & $\checkmark$ \\
\hline Availability of Instant Messaging & $\checkmark$ & $\checkmark$ & $\checkmark$ & $\checkmark$ & & \\
\hline Availability of Discussion board & $\checkmark$ & $\checkmark$ & $\checkmark$ & $\checkmark$ & & $\checkmark$ \\
\hline Personal Workplace & PS 1 & PS 2 & PS 3 & PS 4 & PS 5 & PS 6 \\
\hline $\begin{array}{l}\text { Ability to perform learning materials management such as } \\
\text { uploading, downloading, storage and more }\end{array}$ & $\checkmark$ & $\checkmark$ & $\checkmark$ & $\checkmark$ & & \\
\hline Provides space for reporting of learning outcomes & & & & $\checkmark$ & $\checkmark$ & $\checkmark$ \\
\hline Allows students to create video recordings for learning materials & & & $\checkmark$ & $\checkmark$ & & $\checkmark$ \\
\hline Has connection to watch educational videos & & & $\checkmark$ & $\checkmark$ & $\checkmark$ & \\
\hline
\end{tabular}




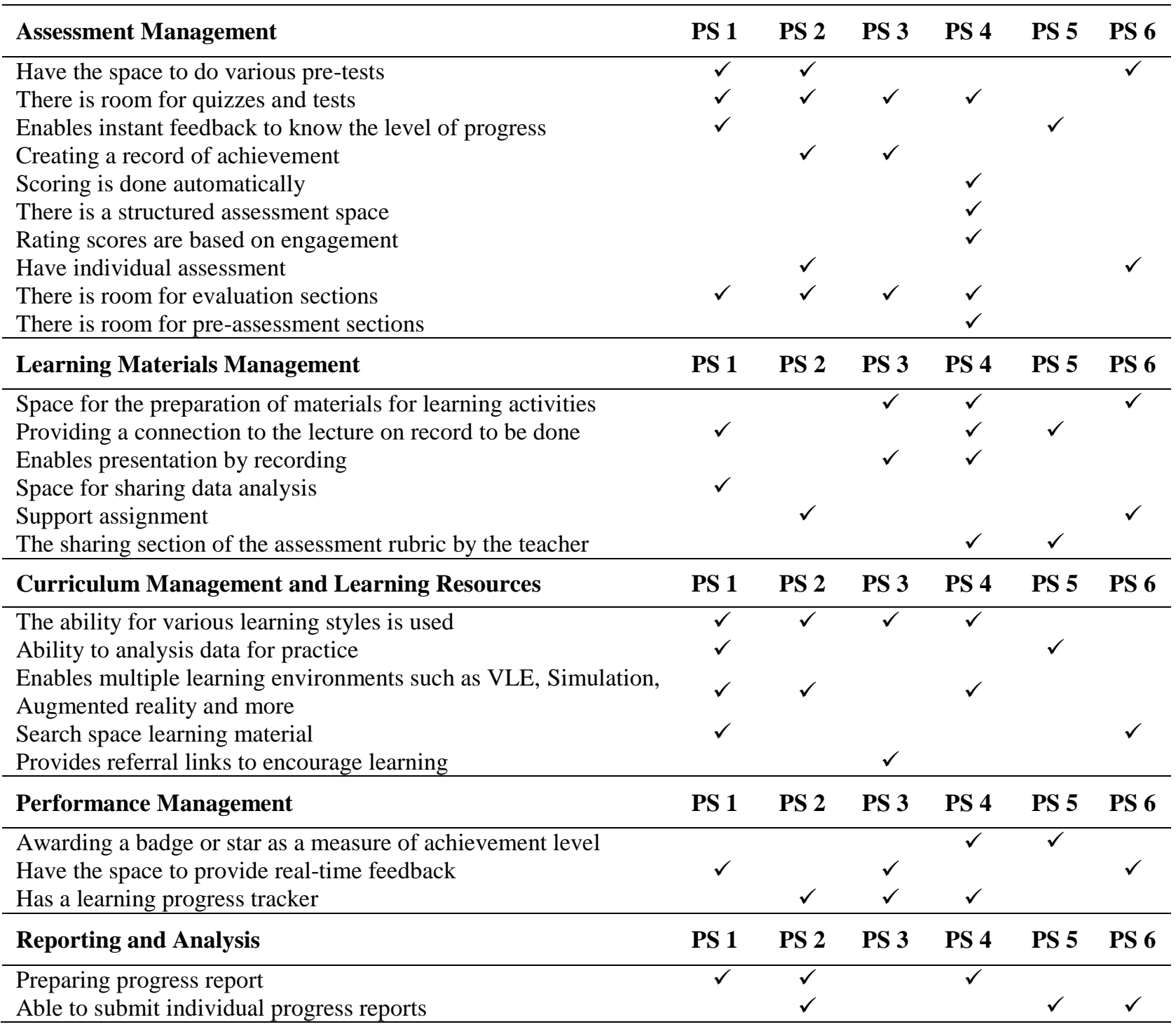

Next, the researchers have verified the interviews data to ensure the validity and reliability of the findings. The verification process is performed by obtaining index inter-rater reliability towards the code and the unit using Kappa Agreement values (Cohen's Kappa). The formula for finding the coefficients of the agreement is as in Figure 1.

Where,

$$
\mathrm{K}=(\text { fo-fc) } /(\mathrm{N}-\mathrm{fc})
$$

$\mathrm{K}=A$ Coefficient of Agreement

$\mathrm{fo}=$ the number of units in which the judges agreed

$\mathrm{fc}=$ the number of units for which agreement is expected by chance

$\mathrm{N}=$ the number of the units coded

\section{Fig. 1 - Formula for Cohen's Kappa}

According to Marohaini (Marohaini, 2001), the reliability of qualitative data can be achieved if the resulting transcripts were reviewed by a panel of judges consisting of at least two independent and credible researchers. Therefore, researchers have chosen two experts in Competency-Based Education and educational technology and formula (Rust \& Cooil, 1994) as shown in Table 2 was referred. Approval of experts in Kappa agreement values is very important in determining the reliability of the themes developed by the researcher. Both experts were provided with a copy of the guidelines and sufficient code schedules. Both must agree on understanding the code and the purpose of the theme (Marohaini, 2001). 
Table 2 - Kappa agreement value scale (Rust \& Cooil, 1994)

\begin{tabular}{cc}
\hline Kappa $(\mathbf{K})$ & Level of Agreement \\
\hline $\mathrm{K}<0.00$ & Very weak \\
$0.00<\mathrm{K}<0.20$ & Weak \\
$0.21<\mathrm{K}<0.40$ & Moderately weak \\
$0.41<\mathrm{K}<0.60$ & Moderate \\
$0.61<\mathrm{K}<0.80$ & Good \\
$0.81<\mathrm{K}$ & Very good \\
\hline
\end{tabular}

As a result of the assessment conducted by 3 experts on 36 elements of CBE in the mobile application, the 36 features of CBE in mobile applications identified and mentioned in Table 1, 3 of them were not approved by one of the two experts after a reliability review. Therefore, these features will be removed from the developed framework. After two evaluators gave their approval, the calculation process was carried out and the agreement value between the inter raters was 0.91. Table 3 below shows the calculation process to get the Cohen Kappa Index Approval Coefficient. According to Rust and Cooil (1994), an agreement value greater than 0.81 indicates a very good reliability scale. Therefore, the building of competency-based Education elements is at a very good level.

Table 3 - The calculation for the Cohen Kappa Index Approval Coefficient

\begin{tabular}{llll}
\hline $\begin{array}{l}\text { Cohen Kappa Expert } \\
\text { Index Approval } \\
\text { Coefficient 1 }\end{array}$ & $\begin{array}{l}\text { Cohen Kappa Expert } \\
\text { Index Approval } \\
\text { Coefficient 2 }\end{array}$ & $\begin{array}{l}\text { Cohen Kappa Expert } \\
\text { Index Approval } \\
\text { Coefficient 3 }\end{array}$ & $\begin{array}{l}\text { Average Coefficient of } \\
\text { Cohen Kappa Index } \\
\text { Approval Rating }\end{array}$ \\
\hline $\mathrm{Fa}=36$ & $\mathrm{Fa}=33$ & $\mathrm{Fa}=33$ & \\
$\mathrm{Fc}=18$ & $\mathrm{Fc}=18$ & $\mathrm{Fc}=18$ & \\
$\mathrm{~N}=36$ & $\mathrm{~N}=36$ & $\mathrm{~N}=36$ \\
$\mathrm{~K}=(\mathrm{Fa}-\mathrm{Fc}) /(\mathrm{N}-\mathrm{Fc})$ & $\mathrm{K}=(\mathrm{Fa}-\mathrm{Fc}) /(\mathrm{N}-\mathrm{Fc})$ & $\mathrm{K}=(\mathrm{Fa}-\mathrm{Fc}) /(\mathrm{N}-\mathrm{Fc})$ & \\
$\mathrm{K}=(36-18) /(36-18)$ & $\mathrm{K}=(33-18) /(36-18)$ & $\mathrm{K}=(34-18) /(36-18)$ & $\mathrm{K}=(1+0.83+0.89) / 3$ \\
$\mathrm{~K}=1$ & $\mathrm{~K}=0.83$ & $\mathrm{~K}=0.89$ & $\mathrm{~K}=0.91$ \\
\hline
\end{tabular}

Therefore, the reliability of coding in this study is very good. This further indicates the high reliability for each unit that is used to describe a theme. Finally, the data obtained from the interviews should be displayed and according to Miles and Huberman (Miles \& Huberman, 1994), there is no specific format for reporting qualitative data research. Thus, researchers have compiled the interviews data in the form of construct arrangement which was obtained with its respective unit. Table 4 is a summary of the elements of the selected element construct after the expert review.

Table 4 - Summary for construct of mobile application for competency-based education (CBE)

\begin{tabular}{lll}
\hline No. & \multicolumn{1}{c}{ Construct } & Features of CBE in Mobile Application \\
\hline 1 & Learning Management & Provides application usage manual for lecturers \\
& Provides application usage manuals for students \\
& Ensure profile management is possible \\
& Able to create a learning group \\
& Availability of Instant Messaging \\
& Availability of Discussion board \\
\hline 2 & Personal Workplace & Ability to perform learning materials management such as \\
& uploading, downloading, storage and more \\
& Provides space for reporting of learning outcomes \\
& Allows students to create video recordings for learning \\
& materials \\
& \\
\hline 3 & Assessment Management & Have the space to do various pre-tests \\
& There is room for quizzes and tests \\
& Enables instant feedback to know the level of progress \\
& Creating a record of achievement \\
& Scoring is done automatically \\
& There is a structured assessment space \\
\hline
\end{tabular}


Table 4 - Continue

\begin{tabular}{lll}
\hline No. & \multicolumn{1}{c}{ Construct } & Features of CBE in Mobile Application \\
\hline 3 & Assessment Management & Rating scores are based on engagement \\
& & Have individual assessment \\
& & There is room for evaluation sections \\
\hline 4 & Learning Materials Management & Space for the preparation of materials for learning activities \\
& & Providing a connection to the lecture on record to be done \\
& & Enables presentation by recording \\
& & Space for sharing data analysis \\
& & Give support assignment \\
& & The sharing section of the assessment rubric by the teacher \\
\hline 5 & Curriculum Management and & The ability for various learning styles is used \\
& Learning Resources & Ability to analyze data for practice \\
& & Enables multiple learning environments such as VLE, \\
& & Simulation, Augmented reality and more \\
& & Search space learning material \\
\hline 6 & Performance Management & Provides referral links to encourage learning \\
\hline 7 & Reporting and Analysis & Have the space to provide real time feedback \\
& & Has a learning progress tracker \\
\hline
\end{tabular}

Based on Table 4, the constructs built for CBE element consists of seven constructs, namely learning management, personal workplace, assessment management, learning materials management, curriculum management and learning resources, performance management and report and analysis. For the first construct which is learning management, the seven elements are; provides application usage manual for lecturers and students, ensure profile management is possible, able to create a learning group and availability of instant messaging and discussion board. The second construct is a personal workplace in mobile apps has three elements which are; ability to perform learning materials management such as uploading, downloading, storage and more, provides space for reporting of learning outcomes and allows students to create video recordings for learning materials. The third construct is assessment management which has nine elements, and the fourth construct is learning materials management has 6 elements. The fifth construct is curriculum management and learning resources has five elements which are; the ability for various learning styles is used, the ability to analyse data for practice, enables multiple learning environments such as VLE, simulation and augmented reality, search space learning material and provides referral links to encourage learning. Construct number six is performance management where the elements are space to provide real-time feedback and a learning progress tracker. The last construct is reporting and analysis where the elements are preparing progress report and able to submit individual progress reports.

\section{Discussion}

The Competency-Based Education (CBE) approach in teaching and learning (T\&L) enables students to take the time they need to understand something large or small (Educause, 2014). This is because the traditional approach is more of a time-based approach where the instructor will spend the assigned syllabus in the allotted time and differences in student ability are not taken into account in the T\&L process (Selamat \& Minghat, 2006). Therefore, in this study, the researcher selected the mobile application platform to apply the CBE approach. As a result of the previous study, this CBE approach was only applied in T\&L by giving students practical, task or project. The approach taken by the researcher is a different one in which the researcher chooses to use this CBE approach in developing concepts for mobile applications.

In the initial phase of the study, the researcher has developed an analytical document in which the researcher obtains information through the reading and exploration of literary works such as journals, reports or seminar papers. As a result of the writing exploration related to the CBE approach, the researcher has listed some of the features of CBE. In the second phase to obtain CBE features in mobile applications, the researcher developed interview questions based on the $\mathrm{CBE}$ features that were found and generated twelve questions. After the second phase is complete, the researcher performs the third phase in which the researcher performs the interview. For the fourth phase, the researcher will perform the analysis of the raw data obtained from the interviews conducted.

As a result of the data analysis, the researcher has divided 36 features of CBE in mobile applications into 7 constructs namely learning management, personal workspace, assessment management, learning materials management, curriculum and learning resources, performance management, and finally, reporting and analysis. This construct was selected by the researchers based on a study conducted by Glowa and Patrick (2014). Next, the construct and elements have gone through a verification process. This stage involved two experts in which these experts would express their agreement on the constructions and features of the CBE that the researcher has listed. After the review, the researchers assessed this 
agreement by 3 elements dropped and obtaining a Cohen Kappa Index Approval Rating where the aggregate for the Cohen Kappa Index Approval Rating is on a very good reliability scale as stated by Rust and Cooil (1994). Therefore, it indicates that this construct is accepted by experts. Therefore, 7 constructs and 33 features of CBE in mobile applications will be used in the development of mobile application frameworks.

According to Glowa and Patrick (2014) in a comprehensive approach to mobile applications, customization of student progress is necessary so that each of them has sufficient time and support to acquire skills at every step. Information technology systems must also be student-centered and academic-based in their data organization. With the development of mobile application frameworks based on these CBE approaches and if the mobile application is developed in accordance with the features and features already mentioned, it will be able to assist students and lecturers in the preparation, repetition and reinforcement of what they are learning. Therefore, mobile applications for Technical and Vocational Education (TVET) to be developed in the future may refer to this study. Throughout this study, researchers were able to develop a CBE based mobile application framework for Technical and Vocational Education. The implication from this research could be used as guidance in the development of the instructional mobile application, particularly in the TVET as an instrument for evaluating existing instructional mobile applications. In conclusion, the development of mobile applications for TVET should have 7 constructs and 33 features that have been identified in this study. Figure 2 below is a mobile apps based on CBE for TVET.

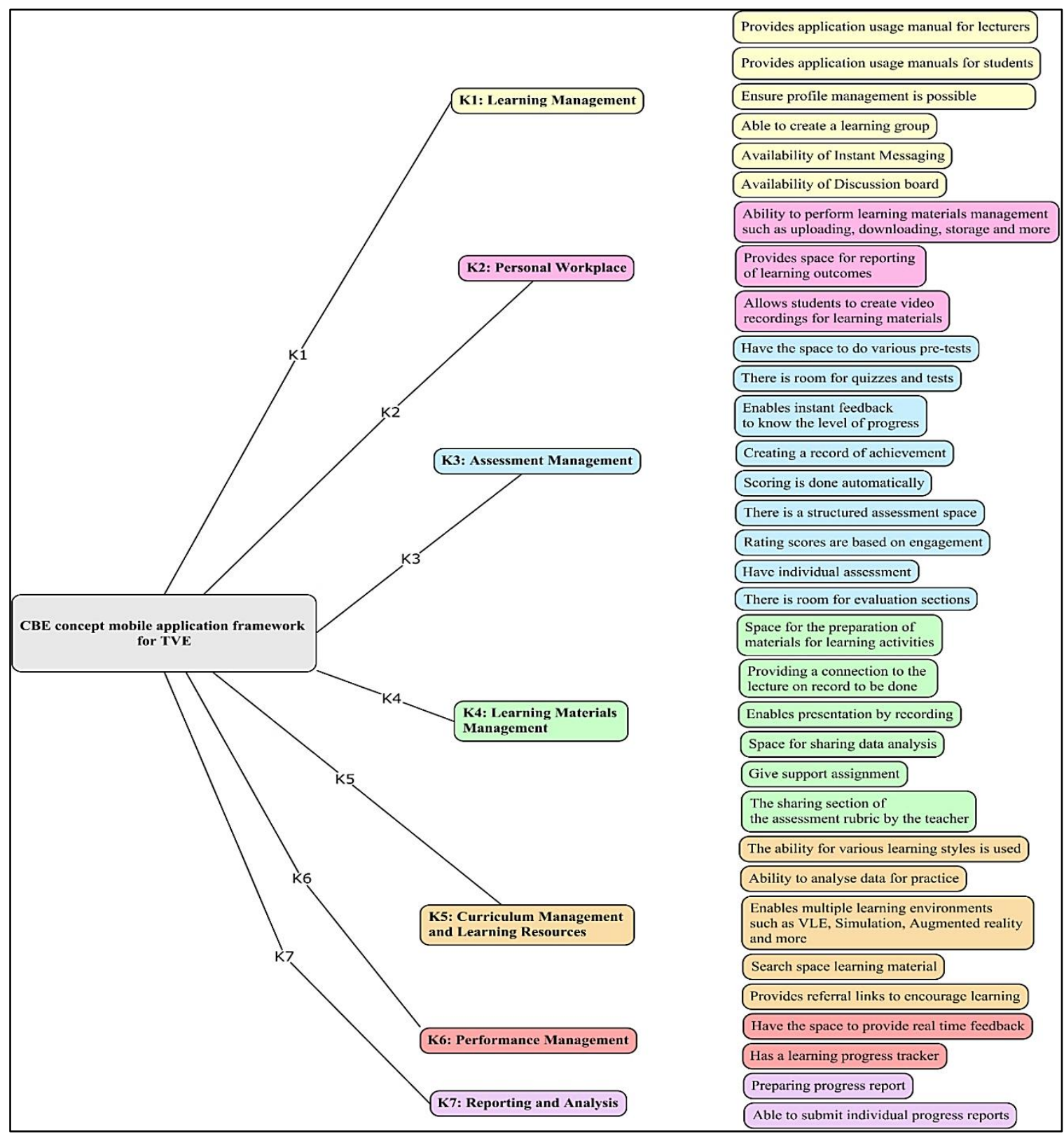

Fig. 2 - Mobile Apps Framework Based on Competency-Based Education for TVET

\section{Conclusion}


These construct frameworks developed can serve as the basis for defining the elements needed to develop a mobile application for Technical and Vocational Education, but they must be student-centered in accordance with Competencybased Education. In Competency-Based Education (CBE) each student moves at their level through adequate support and time for full mastery. Therefore, the mobile system or application developed should be student-oriented in the data organization as well as the interface used and emphasizes skills. The overall result of this study is to benefit various stakeholders, especially the Ministry of Education Malaysia in providing a mobile application platform dedicated to Technical and Vocational Education so that lecturers and students can prepare, repeat and reinforce their learning using the application. The Covid-19 issues today, give advantages, emphasis and encouragement to support delivery learning based on skill by mobile applications.

\section{Acknowledgement}

The authors would like to express their appreciation to the Faculty of Technical and Vocational Education and the Human Capital Development Unit, Registrar's Office, Universiti Tun Hussein Onn Malaysia for the fund to attend the $7^{\text {th }}$ World Conference on Technical \& Vocational Education \& Training 2020 (WOCTVET2020) for the presentation and publication of this article.

\section{References}

Abdul Rahman K. A., Saud, M.S., Kamin, Y. \& Abu Samah, N (2016). Characteristic of Video Learning Based on Project-Oriented Problem Based Learning. International Journal of Education and Training, 1 (1) 1-9

Ali, R.A., Arshad, M.R.M (2016). Perspectives of Students' Behavior Towards Mobile Learning (M-learning) in Egypt: An Extension of the UTAUT Model. Engineering, Technology and Applied Science Research, 6,4. 1109-1114

Ayonmike, C. S., Okwelle, P. C., \& Okeke, B. C. (2014). Competency Based Education and Training in Technical Vocational Education: Implication for Sustainable National Security and Development Department of Technical and Business Education. Journal of Educational Policy and Entrepreneurial Research, 1 (2), 290-300

Azmi, S., Mat Noor, S. F., \& Mohamed, H. (2017). A Proposed Model of M-Learning for Technical and Vocational Education Training (TVET) Students. Journal of Theoretical and Applied Information Technology, 95 (12), 1-11

Creswell, J. W. (2013). Research design: Qualitative, quantitative, and mixed methods approach: Sage publications

Crompton, H., Burke,D (2018). The use of mobile learning in higher education: A systematic review. Computer and Education, 123, August. 53-64

Eden Dahlstrom, D. Christopher Brooks, and Jacqueline Bichsel (2014). The Current Ecosystem of Learning Management Systems in Higher Education: Student, Faculty, and IT Perspectives. Educause Center for Analysis and Research (EDUCAUSE)

Eteokleous, N.; Ktoridou, D (2009). Investigating Mobile Devices Integration in Higher Education in Cyprus: Faculty Perspectives. International Journal of Interactive Mobile Technologies, 3 (1), 38-48

Glowa, L., Patrick, Susan (2013). Re-Engineering Information Technology: Design Considerations for Competency Education. International Association for K-12 Online Learning

Graham, K. (2015). TechMatters: Getting into Kahoot! (s): Exploring a game-based learning system to enhance student learning. LOEX Quarterly, 42 (3), 6-7

Hernández-Ramos, P. (2007). Aim, shoot, ready! Future teachers learn to 'do' video. British Journal of Educational Technology, 38 (1), 33-41

Jasmi, K. A., Tamuri, A. H., \& Mohd Hamzah, M. I. (2011). Kajian Kes Penggunaan Kaedah Pengajaran Dan Pembelajaran Guru Cemerlang Pendidikan Islam (GCPI) Sekolah Bandar Dan Luar Bandar: Satu Kajian Perbandingan [A case study of the high performance urban and rural teacher's application of teaching and learning on Islamic education: a comparative study]. Jurnal Teknologi, 56 (1), 179-198

Kandar, S., \& Asnul Dahar, M. (2006). Memenuhi Keperluan Modal Insan Melalui Latihan Berasaskan Ketrampilan $(L B K)$ [fulfilling the human capital needs through competency-based training]. Proceeding of TVE06. Johor: Universiti Teknologi Malaysia

Lokman, M. T., Nurul Qistin, M., \& Mohd Hanafi, M. Y. (2009). Pendidikan Teknik Dan Vokasional Untuk Pelajar Berkeperluan Khas [TVET for special need students]. Jurnal Pendidik dan Pendidikan, 24 (1). 73-87

Lee, M.-K. (2018). Flipped classroom as an alternative future class model? implications of South Korea's social experiment. Educational Technology Research and Development, 66 (3), 837-857 
Licorish, S. A., Owen, H. E., Daniel, B., \& George, J. L. (2018). Students' perception of Kahoot!'s influence on teaching and learning. Research and Practice in Technology Enhanced Learning, 13(9), 1-23

Marohaini, Y. (2001). Penyelidikan Kualitatif Pengalaman Kerja Lapangan Kajian [a field study research using qualitative approach]. Kuala Lumpur: Universiti Malaya

Masran, S. H., Marian, M. F., Nur Yunus, F. A., Rahim, M. B., \& Abd Baser, J. (2017). Effectiveness of Using an Interactive Media in Teaching and Learning: A Case Study. Proceeding of the IEEE 9th International Conference on Engineering Education (ICEED) (222-227). Kanazawa: IEEE

Miles, M. B., \& Huberman, A. M. (1994). An Expanded Sourcebook: Qualitative Data Analysis (2 ${ }^{\text {nd }}$ ed). Thousand Oaks, London dan New Delhi: SAGE Publications

Muslimin, M. S., Nordin, N. M., Mansor, A. Z., \& Yunus, M. M. (2017). The Design and Development of MobiEko: A Mobile Educational App for Microeconomics Module. Malaysian Journal of Learning and Instruction: Special Issue, $221-255$

Norris, C., Hossain. A., Soloway. E (2011). Using Smartphones as Essential Tools for Learning: A Call to Place Schools on the Right Side of the 21st Century. Educational Technology, 51(3), 18-25

Rust, R., \& Cooil, B. (1994). Reliability Measure for Qualitative Data: Theory and Implications. Journal of Marketing Research, 31,1, 1-14

Serrano, M. M., O'Brien, M., Roberts, K., \& Whyte, D. (2018). Critical Pedagogy and assessment in higher education: The ideal of 'authenticity' in learning. Active Learning in Higher Education, 19(1), 9-21

Shaharuddin, M. S., \& Ahmad Khairi, M. A. (2011). Pembangunan Web E Pembelajaran Menggunakan Elemen Video Dalam Topik 'Work and Energy' Berasaskan Teori Konstruktivisme Sosial [Web E development using video for 'work and energy' based on Social Constructivism Theory]. Johor: Universiti Teknologi Malaysia

Simah, M., Che Aleha, L., Azni Yati, K., Siti Mariah, M \& Nor Asiah Ismail (2021). Covid-19: Cabaran dan Pelaksanaan Pengajaran dan Pembelajaran Teradun [Covid-19: challenges and implementation of blended teaching and learning]. Proceeding of the 'Majlis Dekan Pendidikan Universiti Awam Malaysia' (MEDC2020) (568-581). Bandar Baru Nilai: Universiti Sains Islam Malaysia 